\title{
Cool early Albian climates; new data from Argentina
}

\author{
D. Pirrie ${ }^{\mathrm{a}, *}$, J.D. Marshall ${ }^{\mathrm{b}}$, P. Doyle ${ }^{\mathrm{c}}$, A.C. Riccardi $^{\mathrm{d}}$ \\ ${ }^{a}$ Camborne School of Mines, University of Exeter, Redruth, Cornwall TR15 3SE, UK \\ ${ }^{\mathrm{b}}$ Department of Earth and Ocean Sciences, University of Liverpool, 4 Brownlow Street, Liverpool L69 3GP, UK \\ ${ }^{\mathrm{c}}$ Department of Geological Sciences, University College London, Gower Street, London WC1E 6BT, UK \\ ${ }^{\mathrm{d}}$ Facultad de Ciencias Naturales, Museo de La Plata, Paseo del Bosque s/n, 1900, La Plata, Argentina
}

Accepted 23 October 2003

\begin{abstract}
Previous studies on the stable isotope geochemistry of dimitobelid belemnites from Antarctica and Australia indicated cool climatic conditions during the early Albian in the shelf seas around the Gondwanan margin. In this paper new analyses from diagenetically unaltered specimens of Dimitobelus cf. stimulus from early Albian deposits of the Rio Mayer Formation of Lago San Martin, southern Argentina are presented. Oxygen isotope values for diagenetically least altered samples give values ranging between $\delta^{18} \mathrm{O}+0.07$ and $+0.96 \mathrm{vPDB}$, which equate to a mean palaeotemperature of $9.5{ }^{\circ} \mathrm{C}\left(\right.$ assuming $\delta_{\mathrm{w}}$ of $-1.2 \% \mathrm{SMOW}$ ). These data are consistent with a model of cool early Albian shelf seas in the Southern Hemisphere.
\end{abstract}

(C) 2004 Elsevier Ltd. All rights reserved.

Keywords: Albian; Palaeoclimates; Argentina; Dimitobelid belemnites

\section{Introduction}

The possibility of intervals of cool climatic conditions, with the development of polar glaciation, during the otherwise greenhouse climate of the Cretaceous is controversial (Sellwood et al., 1994; Stoll and Schrag, 2000; Huber et al., 2002). Results that have been used to support the possibility of cool climatic intervals in the Cretaceous include: data from palaeobotanical studies (e.g. Francis and Poole, 2002), stable isotope analyses (Rich et al., 1988; Gregory et al., 1989; Ditchfield et al., 1994; Pirrie et al., 1995; Stoll and Schrag, 2000), sequence stratigraphic boundaries and linked $\delta^{18} \mathrm{O}$ increases (Miller et al., 1999, 2003), dropstones interpreted to be of glacial origin (Frakes and Francis, 1988; Frakes et al., 1992), global climate models (Price et al., 1998) and sedimentary structures interpreted to be the result of cryoturbation (Constantine et al., 1998). However, oxygen isotope data from planktonic and benthic foraminifera from numerous Deep Sea Drilling Project (DSDP) and Ocean Drilling Programme (ODP)

\footnotetext{
* Corresponding author. Tel.: +44-1209-714866; fax: +44-1209716977.

E-mail address: dpirrie@csm.ex.ac.uk (D. Pirrie).
}

sites indicate that Cretaceous ocean temperatures were much higher than at present and incompatible with intervals of polar glaciation (Clarke and Jenkyns, 1999; Huber et al., 1995, 2002). To resolve this controversy additional data sets are needed. Possibly the most widely documented potential icehouse interval in the Cretaceous is a major cooling event during the late Aptian and early Albian (e.g. Pirrie et al., 1995). In this study new stable isotope data from dimitobelid belemnites from early Albian deposits in Argentina are presented. These data are comparable with previous data for dimitobelid belemnites from Antarctica (Ditchfield et al., 1994) and Australia (Pirrie et al., 1995) and are consistent with the interpretation of cool climatic conditions in the high palaeolatitudes of the Southern Hemisphere during the early Albian.

\section{Regional setting and previous work}

Samples of the belemnite Dimitobelus cf. stimulus were selected for analysis from the palaeontological collections of the Museo de La Plata, Universidad de la Plata, Argentina. The samples were collected from early 


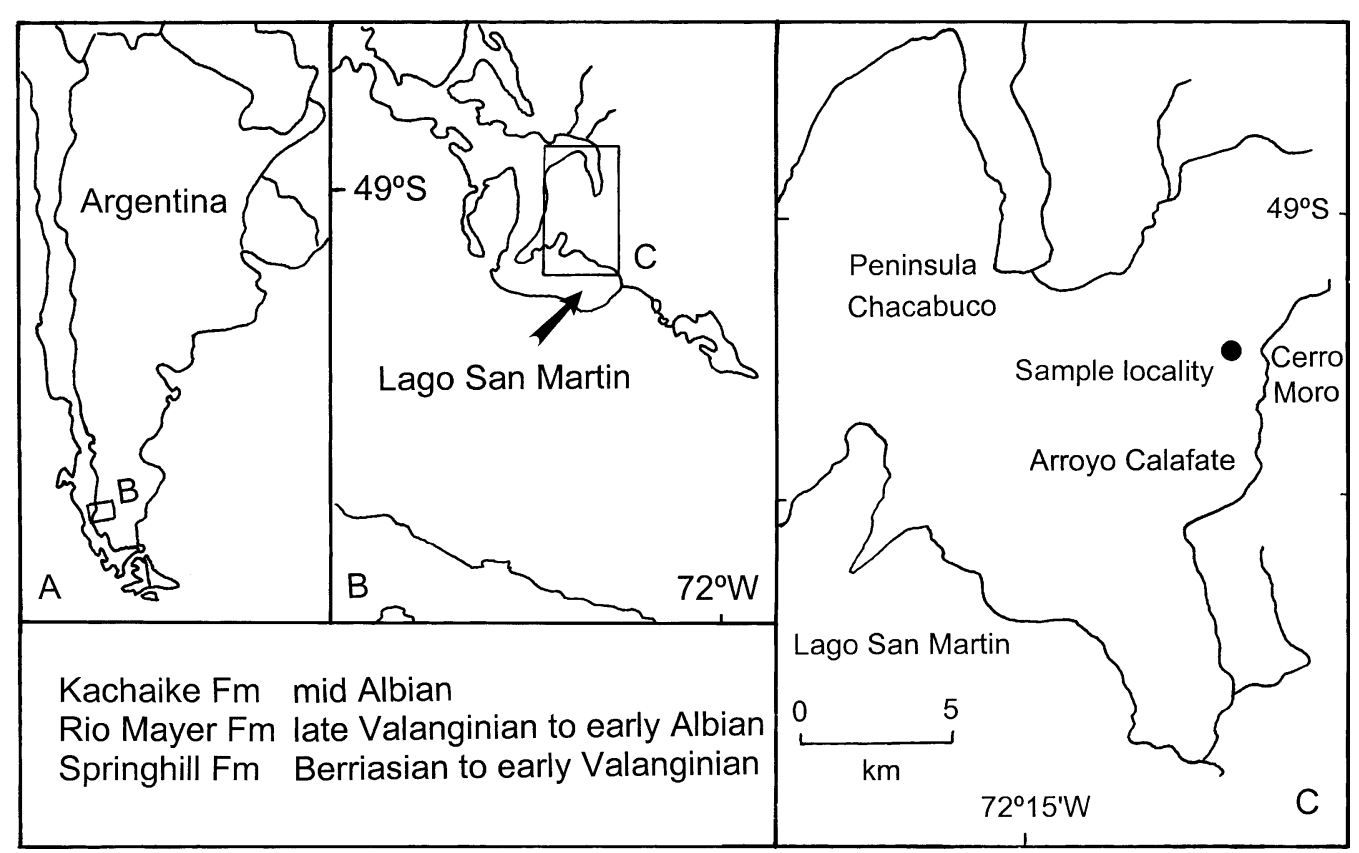

Fig. 1. Sketch map showing the location of the sampled interval in the Rio Mayer Formation in the Arroyo Calafate.

Albian levels of the Rio Mayer Formation, Lago San Martin, southern Argentina (Riccardi and Aguirre Urreta, 1987; Riccardi, 1988) (Fig. 1). The sampled locality $\left(49^{\circ} 02^{\prime} \mathrm{S}, 72^{\circ} 08^{\prime} \mathrm{W}\right)$ is documented by Riccardi (1971). The succession is exposed on the eastern limb of a broad anticline that covers a core of Palaeozoic rocks which are exposed on the western and eastern shores of Peninsula Chacabuco. The regional dip of the Mesozoic succession is $5-25^{\circ} \mathrm{ESE}$. Although thick (ca. $3 \mathrm{~m}$ ) essexite sills occur $50 \mathrm{~m}$ above the sampled levels, there is no evidence for any diagenetic alteration of the belemnites as a result of the emplacement of the sills. The Cretaceous sediments in the area (see Riccardi, 1988) overlie Jurassic volcanic rocks of the El Quemado Complex and consist of Berriasian-early Valanginian continental to marine sandstones of the Springhill Formation; the late Valanginian-early Albian marine black shales of the Rio Mayer Formation; and the mid Albian shallow marine to continental sandstones of the Kachaike Formation.

The early Albian levels of the Rio Mayer Formation have been divided into two assemblage zones on the basis of its ammonoids (see Riccardi and Medina, 2002): the index species are, from the base, Aioloceras argentinum and A. rollerii. The samples studied were collected from the argentinum Assemblage Zone, which is characterised by: $A$. argentinum (Bonarelli), Maccoyella bonarellii (Leanza), Puzosia recteradiata (Collignon), Rossalites imlayi (Leanza) and perhaps Douvilleiceras sp., Phylloceras sp. and Protanisoceras sp. The argentinum and rollerii zones are coeval with the Mammillatum Standard Superzone, which most probably correlates with the upper Chalensis and lower Auritiformis Standard zones (see Riccardi and Medina, 2002). This correlation is based on several genera and species that link the Patagonian faunas with those from Madagascar and Tethys (Riccardi and Medina, 2002).

There are very few previously published oxygen isotope palaeotemperature studies for the Cretaceous of southern Argentina. Bowen (1961, 1963) presented results from a number of samples that are poorly constrained stratigraphically. Among these Cretaceous samples several from near Lago San Martin gave $\delta^{18} \mathrm{O}$ values of between -2.8 and $-3.5 \%$, which would equate to much higher palaeotemperatures than reported here. The lack of diagenetic screening casts doubt on the reliability of these preliminary data, although it is also possible that they were collected from a different stratigraphic level in the Cretaceous succession exposed at Lago San Martin.

\section{Palaeobiogeography of the Dimitobelidae}

The Dimitobelidae are unusual as a distinct and easily recognisable group of belemnites that have a wholly Gondwanan distribution pattern (Whitehouse, 1924). Reviews of the biogeography of the Dimitobelidae include Stevens (1965), and more recently Doyle (1988, 1990, 1992) and Doyle and Pirrie (1999). It is generally held that the group is representative of a marine Austral Realm that developed towards the close of the Early Cretaceous period and continued through to the end of the Cretaceous. The Dimitobelidae are 
representative of the boundaries of the realm, and comprise the genera Peratobelus, Tetrabelus and Dimitobelus (including the subgenus Dimitocamax).

Doyle $(1988,1990)$ has pointed out the presence of at least two distinct faunas within the dimitobeliddominated Austral Realm, defined on the basis of the presence or absence of the genus Tetrabelus. This genus is only known from the Aptian/Albian of southern India and James Ross Island, Antarctica.

The second fauna is dominated by Dimitobelus itself, which is geographically widespread within Gondwana. Apart from the largely endemic New Zealand species (Stevens, 1965), Albian Dimitobelus species are remarkably uniform across Gondwana, with the most widespread being the group comprising $D$. diptychus, $D$. stimulus, and D. stimulus var. extremis (Doyle, 1987, 1990). The importance of this group to biogeographers and palaeoclimatologists is its overall uniformity and consistency, with the same closely related taxa occurring in close geographical association. As such the $D$. diptychus group is common in Argentina, the Antarctic Peninsula and Australia, and is also present in other Gondwanan territories (Stevens, 1965; Ludbrook, 1966; Doyle, 1987, 1988, 1990; Riccardi, 1988). Pirrie and Marshall (1990), Ditchfield et al. (1994) and Pirrie et al. (1995) have used belemnites from this dominant group in their palaeotemperature studies, and the use of belemnites from the same group in this study validates comparison of the oxygen isotope composition and calculated palaeotemperatures across all three studies, and therefore latitudinally, across Gondwana.

However, although belemnites have been used widely in palaeotemperature studies, partly because the rostra are considered to be diagenetically stable low $\mathrm{Mg}$ calcite, some work has shown an apparent offset between the oxygen isotopic composition of belemnites (which are typically heavier) and benthic organisms from the same sections (e.g. Voigt et al., 2003). In most studies though, there is no evidence for an isotopic offset between belemnites and other molluscan taxonomic groups from the same sections and this has been taken to indicate that there are no significant vital effects during calcification of the belemnite rostra. The isotopic offset reported in some studies may reflect a limitation of our understanding of belemnite palaeobiology. Despite the fact that belemnites most commonly occur within sedimentary rocks, interpreted to have been deposited within shelf environments, the life habitats and water depth at which the rostra calcified is equivocal. Isotopic studies on Jurassic belemnites have indicated that at least some taxa were nektobenthonic within a shelf setting (Anderson et al., 1994). However, belemnite biogeography studies (e.g. Doyle, 1992) suggest that, while some belemnites were shelf dwelling, other taxa were nektonic and it is possible that the rostra were calcified in deep water environments. Palaeogeographical studies of the Dimitobelidae suggest that this family of belemnites was predominantly restricted to shelf settings (Doyle and Pirrie, 1999), although in the James Ross Basin, Antarctica, dimitobelids occur in the deep marine slope apron and submarine fan complex of the Kotick Point and Whisky Bay formations (Doyle, 1987; Ineson, 1989). However, these belemnites are commonly fragmentary and abraded and may have been resedimented within high concentration turbidity currents sourced from the adjacent shelf (DP, pers. obs., 2002). In addition to understanding the depth at which the calcification of the rostra occurred, another factor that needs to be considered when interpreting the palaeoclimatic significance of the data is the oxygen isotopic composition of the seawater in which the taxa lived. Although the Austral Basin was semi-restricted in the Hauterivian there was improved oceanic circulation by the Aptian-Albian, allowing the migration of a more diversified marine fauna. While some recent work on the Western Interior Seaway in the US has demonstrated that some ammonites were tolerant of somewhat brackish-water conditions (Cochran et al., 2003), there is no evidence to suggest that belemnites were anything other than fully marine organisms. Consequently, it is assumed that the belmnite rostra were calcified within open marine conditions. Thus, whilst oxygen isotope data from dimitobelid belemnites cannot be considered to necessarily reflect sea-surface temperatures (SST) it is highly likely that they are indicative of shelf sea temperatures.

\section{Analytical methods}

Ten belemnite rostra of the species Dimitobelus cf. stimulus were examined in this study. Half of each rostrum was thin sectioned and examined using standard petrography, cathodoluminescence (CL) (using a Technosyn cold cathode luminoscope at $15-20 \mathrm{kV}$ and gun currents of $400-500 \mu \mathrm{A}$ ) and after carbonate staining (following Dickson, 1966). Using the petrographic data (see below) as a guide, single subsamples of carbonate powder were collected from non-luminescent non-ferroan areas of each rostrum using a dental drill for stable isotope and trace element geochemistry. Samples for stable isotope analysis had any organic contamination removed by roasting the carbonate powder in a low temperature plasma oven for $3 \mathrm{~h}$. $\mathrm{CO}_{2}$ gas was generated for analysis by reacting the sample with $100 \%$ orthophosphoric acid at $25^{\circ} \mathrm{C}$. The liberated $\mathrm{CO}_{2}$ was analysed using a modified VG Isogas SIRA 12 mass spectrometer at the University of Liverpool stable isotope laboratory. Results are reported in standard $\delta$ notation relative to vPDB. Reproducibility for both $\delta^{18} \mathrm{O}$ and $\delta^{13} \mathrm{C}$ is better than 
$0.1 \%$. Carbonate powder subsamples were analysed by $\mathrm{ICP}$ for $\mathrm{Fe}, \mathrm{Mn}, \mathrm{Mg}$ and $\mathrm{Sr}$.

\section{Sample preservation and geochemistry}

The rostra are largely composed of radially arranged clear calcite that is both non-ferroan and non-luminescent. Inclusion-rich calcite occurs at the centre of the rostra and within widely spaced growth lines. The majority of each of the rostra are non-luminescent and non-ferroan. Minor orange luminescent ferroan calcite cements occur within microfractures cross-cutting the rostra, replacing both individual growth lines and the centre of the rostra and also occurring as cements around the edge of the rostra. Subsamples for trace element and stable isotopic analysis were drilled from areas away from the ferroan calcite cements in parts of the rostra composed of non-luminescent non-ferroan calcite. The trace element geochemistry of the subsamples have Mn values of less than 34 ppm and less than 84 ppm $\mathrm{Fe}$ although there is an apparent weak covariance between the $\mathrm{Fe}$ and $\mathrm{Mn}$ data (Fig. 2A). Sr values vary from 1680 to $2373 \mathrm{ppm}$, with $\mathrm{Mg}$ ranging from 1093 to $1576 \mathrm{ppm}$ (Table 1). The trace element data are consistent with the interpretation that the belemnite rostra are unaltered (Marshall, 1992). Measured $\delta^{18} \mathrm{O}$ values range between +0.07 and $+0.96 \%$ vPDB, with a single outlying value of $-1.88 \%(\mathrm{C} 210) . \delta^{13} \mathrm{C}$ ranges between +0.38 and $+2.47 \%$ (Table 1, Fig. 2B). Based on the thin section petrography, trace element geochemistry and isotopic composition, all of the samples except $\mathrm{C} 210$ are considered to represent diagenetically minimally altered original low $\mathrm{Mg}$ calcite.

\section{Palaeotemperature calculations}

Palaeotemperature values for calcite samples can be calculated using a modified version of the Craig palaeotemperature equation, as given in Anderson and Arthur (1983) and used in previous studies (e.g. Pirrie et al., 1995):

$T^{\circ} \mathrm{C}=16.0-4.14\left(\delta_{\mathrm{c}}-\delta_{\mathrm{w}}\right)+0.13\left(\delta_{\mathrm{c}}-\delta_{\mathrm{w}}\right)^{2}$

where $\delta_{\mathrm{c}}=\delta^{18} \mathrm{O}(\mathrm{vPDB})$ of the analysed carbonate at $25{ }^{\circ} \mathrm{C}$ and $\delta_{\mathrm{w}}=\delta^{18} \mathrm{O}$ (SMOW) of the water in which the carbonate was precipitated relative to the 'Standard Mean Ocean Water' international standard. While $\delta_{\mathrm{c}}$ is measured, $\delta_{\mathrm{w}}$ has to be estimated. This is problematic because (1) $\delta_{\mathrm{w}}$ varies within the present oceans and (2) average $\delta_{\mathrm{w}}$ has varied throughout geological time (Hudson and Anderson, 1989). It is important to note that temperature decrease and global ice-volume build up (and consequent oceanic ${ }^{18} \mathrm{O}$ enrichment), will have a similar effect on $\delta_{\mathrm{c}}$. For periods of limited or no glaciation, global average $\delta_{\mathrm{w}}$ values are estimated to be $-1.2 \%$ SMOW (Shackleton and Kennett, 1975; see discussion in Hudson and Anderson, 1989). In this study palaeotemperatures have been calculated using a $\delta_{\mathrm{w}}$ value of $-1.2 \%$. Calculated palaeotemperatures range between 7.7 and $10.9^{\circ} \mathrm{C}$ (mean $9.5^{\circ} \mathrm{C}$ ) (Table 2).

\section{Discussion}

These new data suggest relatively cool temperatures for the early Albian of Argentina at a palaeolatitude of approximately $58^{\circ} \mathrm{S}$. These data can be directly compared with previous work on dimitobelid belemnites

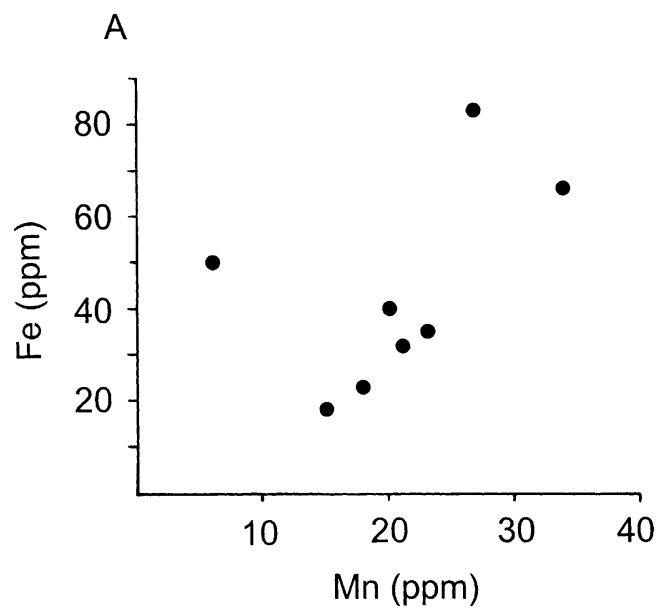

B

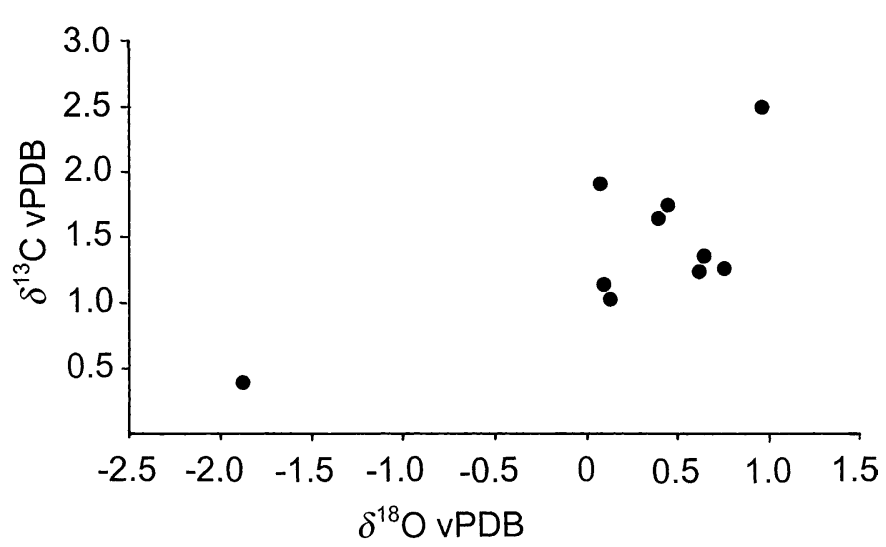

Fig. 2. (A) Fe vs. Mn cross plot; although there is covariance between Fe and Mn, all of the values are low and are compatible with skeletal carbonates showing minimal diagenetic alteration. (B) $\delta^{18} \mathrm{O}$ vs. $\delta^{13} \mathrm{C}$ cross plot for Dimitobelus cf. stimulus from Argentina; the outlying sample (C210) is considered to be diagenetically altered. 
Table 1

Stable isotope and trace element geochemistry for Dimitobelus cf. stimulus from the early Albian Rio Mayer Formation, Lago San Martin, Argentina; bd, below detection limits

\begin{tabular}{lllllllr}
\hline Sample & $\begin{array}{l}\delta^{18} \mathrm{O} \\
(\%)\end{array}$ & $\begin{array}{l}\delta^{13} \mathrm{C} \\
(\%)\end{array}$ & $\begin{array}{l}\mathrm{Mn} \\
(\mathrm{ppm})\end{array}$ & $\begin{array}{l}\mathrm{Fe} \\
(\mathrm{ppm})\end{array}$ & $\begin{array}{l}\mathrm{Sr} \\
(\mathrm{ppm})\end{array}$ & $\begin{array}{l}\mathrm{Mg} \\
(\mathrm{ppm})\end{array}$ & $\begin{array}{l}T \\
\left({ }^{\circ} \mathrm{C}\right)\end{array}$ \\
\hline $\mathrm{C} 210$ & -1.88 & +0.38 & 27 & 83 & 2373 & 1181 & - \\
$\mathrm{C} 211$ & +0.64 & +1.33 & 18 & 23 & 1744 & 1425 & 8.8 \\
$\mathrm{C} 212$ & +0.09 & +1.12 & 15 & 18 & 1729 & 1093 & 10.9 \\
$\mathrm{C} 215$ & +0.96 & +2.47 & $\mathrm{bd}$ & $\mathrm{bd}$ & 1807 & 1360 & 7.7 \\
$\mathrm{C} 216$ & +0.45 & +1.72 & 21 & 32 & 1901 & 1284 & 9.5 \\
$\mathrm{C} 220$ & +0.12 & +1.01 & $\mathrm{bd}$ & $\mathrm{bd}$ & 2209 & 1323 & 10.8 \\
$\mathrm{C} 222$ & +0.4 & +1.62 & 20 & 40 & 1791 & 1233 & 9.7 \\
$\mathrm{C} 223$ & +0.76 & +1.24 & 23 & 35 & 1680 & 1312 & 8.4 \\
$\mathrm{C} 227$ & +0.07 & +1.89 & 34 & 66 & 1945 & 1576 & 10.9 \\
$\mathrm{C} 231$ & +0.61 & +1.22 & 6 & 50 & 2027 & 1240 & 8.9 \\
\hline
\end{tabular}

Calculated palaeotemperatures are also given assuming a $\delta_{\mathrm{w}}$ value of $-1.2 \%$. Note that sample $\mathrm{C} 210$ is considered to be diagenetically altered based on the anomalously low $\delta^{18} \mathrm{O}$ value and is not used to calculate a palaeotemperature.

belonging to the $D$. diptychus group from Antarctica and Australia (Fig. 3). Ditchfield et al. (1994) examined specimens of Dimitobelus from the Kotick Point Formation, James Ross Basin, Antarctica. During the Albian, the James Ross Basin was located at a palaeolatitude of ca. $65^{\circ} \mathrm{S}$. Recent palynological biostratigraphic studies have revised the age of the Kotick Point Formation, which is now considered to be mainly early Albian in age, although the uppermost part of the formation may span up into the mid Albian (Riding and Crame, 2002). Based on thin section petrography, and isotopic composition, 10 samples of Dimitobelus (most probably $D$. stimulus, one of the members of the $D$. diptychus group) were considered by Ditchfield et al. (1994) to be diagenetically unaltered and had a range in $\delta^{18} \mathrm{O}$ values of between +0.13 and $+1.40 \%$. Using a $\delta_{\mathrm{w}}$ value of $-1.2 \%$ (SMOW) calculated palaeotemperatures for these data range between 6.1 and $10.7^{\circ} \mathrm{C}$ (Table 2) and have a mean of $8.5^{\circ} \mathrm{C}$.

Pirrie et al. (1995) analysed the stable isotope geochemistry of 17 samples of Dimitobelus stimulus and D. dipthycus from the early-mid Albian Gearle Siltstone, Carnarvon Basin, Western Australia. The Gearle Siltstone was deposited at a palaeolatitude of $55^{\circ} \mathrm{S}$ during the Albian. All of the samples showed partial replacement by light blue luminescing quartz, while the rest of the rostra comprised clear, nonluminescent non-ferroan calcite other than orange

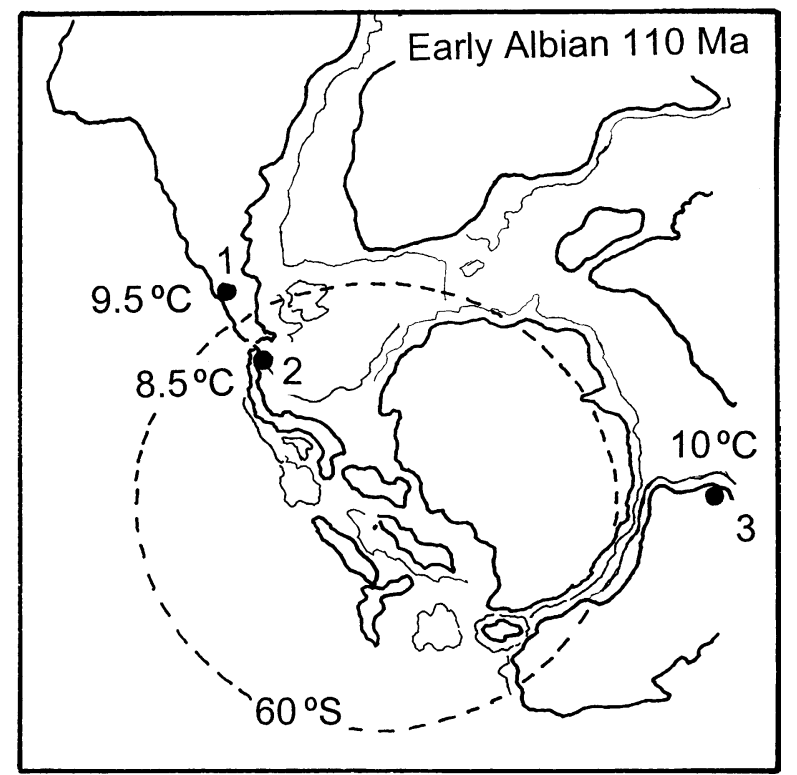

Fig. 3. Schematic plate tectonic reconstruction for the early Albian showing the sampling locations in: (1) Lago San Martin (Argentina), (2) Antarctica (James Ross Basin) and (3) Australia (Carnarvon Basin). Average calculated palaeotemperatures assuming a $\delta_{\mathrm{w}}$ of $-1.2 \%$ are also shown.

luminescent calcite infilling very thin microfractures that cross-cut the rostra. Carbonate staining guided sampling of non-ferroan calcite that was considered to be diagenetically unaltered. The samples have a range in $\delta^{18} \mathrm{O}$ values between -0.02 and $+0.85 \%$. Using a $\delta_{\mathrm{w}}$ value of $-1.2 \%$ (SMOW) calculated palaeotemperatures for these data range between 7.8 and $11.3{ }^{\circ} \mathrm{C}$ (mean $10.1{ }^{\circ} \mathrm{C}$ ) (Table 2).

Together these data suggest that shelf seawater temperatures around the Gondwanan margin during the early Albian were relatively cool, assuming of course, that the Dimitobelidae, and in particular, the D. diptychus group, were shelf-dwelling nektobenthonic organisms. Erbacher et al. (2001) have previously recorded positive $\delta^{18} \mathrm{O}$ values for both benthic and planktonic foraminifera in the early Albian. These data were attributed to either cool water temperatures and/or high salinities. Although cool, the palaeotemperature estimate for the dimitobelid data is probably not cold enough to support the presence of significant polar glaciation at this time, although limited montane glaciation was possible at intervals in the Cretaceous

Table 2

Comparison of the measured oxygen isotope composition, calculated palaeotemperatures and palaeolatitudes for Lago San Martin (Argentina), the James Ross Basin (Antarctica) (Ditchfield et al., 1994) and the Carnarvon Basin (Australia) (Pirrie et al., 1995)

\begin{tabular}{|c|c|c|c|c|c|}
\hline Location & Stratigraphy & Palaeolatitude & $\delta^{18} \mathrm{O}$ (range) & $T^{\circ} \mathrm{C}$ (range) & $\overline{T^{\circ} \mathrm{C} \text { (mean) }}$ \\
\hline Lago San Martin (Argentina) & Rio Mayer Fm (early Albian) & $58^{\circ} \mathrm{S}$ & +0.07 to +0.96 & $7.7-10.9$ & 9.5 \\
\hline James Ross Island (Antarctica) & Kotick Point Fm (early to mid Albian) & $65^{\circ} \mathrm{S}$ & +0.13 to +1.40 & $6.1-10.7$ & 8.5 \\
\hline Carnarvon Basin (Australia) & Gearle Siltstone (early to mid Albian) & $55^{\circ} \mathrm{S}$ & -0.02 to +0.93 & $7.8-11.3$ & 10.1 \\
\hline
\end{tabular}


(cf. Miller et al., 2003). The data also support low latitudinal temperature gradients. Huber et al. (2002) suggested a sea-surface latitudinal temperature gradient in the late Albian of $0.25^{\circ} \mathrm{C}$ per degree of latitude, while the early Albian belemnite data presented here suggest a slightly lower latitudinal temperature gradient of, at most, $0.16{ }^{\circ} \mathrm{C}$ per degree of latitude, although a linear latitudinal gradient is unlikely. Clearly, there was no significant temperature variation between South America and Antarctica in the early Albian. However, what is clear is that the shelf seas of Gondwana were relatively cool during the early Albian, a time during which a distinct marine Austral realm was present.

\section{Acknowledgements}

Funding for this study was provided via NERC grant GR9/1045 to DP, PD and JDM. We thank Julian Curnow for preparing the thin sections of the dimitobelids. The manuscript was completed while the senior author was on study leave from the University of Exeter, which is acknowledged. We are grateful for the referees' comments and editing by David Batten which tightened up the final manuscript.

\section{References}

Anderson, T.F., Arthur, M.A., 1983. Stable isotopes of oxygen and carbon and their application to sedimentological and palaeoenvironmental problems. In: Arthur, M.A., Anderson, T.F., Kaplan, I.R., Veizer, J., Land, L.S. (Eds.), Stable Isotopes in Sedimentary Geochemistry. SEPM, Short Course Notes 10, pp. 1-151.

Anderson, T.F., Popp, B.N., Williams, A.C., Ho, L.-Z., Hudson, J.D., 1994. The stable isotopic record of fossils from the Peterborough Member, Oxford Clay Formation (Jurassic), UK: palaeoenvironmental implications. Journal of the Geological Society, London 151, 125-138.

Bowen, R., 1961. Paleotemperature analyses of Mesozoic belemnoidea from Australia and New Guinea. Geological Society of America, Bulletin 72, 769-774.

Bowen, R., 1963. $\mathrm{O}^{18} / \mathrm{O}^{16}$ paleotemperature measurements on Mesozoic Belemnoidea from Neuquen and Santa Cruz provinces, Argentina. Journal of Paleontology 37, 714-718.

Clarke, L.J., Jenkyns, H.C., 1999. New oxygen isotope evidence for long-term Cretaceous climatic change in the Southern Hemisphere. Geology 27, 699-702.

Cochran, J.K., Landman, N.H., Turekian, K.K., Michard, A., Schrag, D.P., 2003. Paleoceanography of the Late Cretaceous (Maastrichtian) Western Interior Seaway of North America: evidence from $\mathrm{Sr}$ and $\mathrm{O}$ isotopes. Palaeogeography, Palaeoclimatology, Palaeoecology 191, 45-64.

Constantine, A., Chinsamy, A., Vickers-Rich, P., Rich, T.H., 1998. Periglacial environments and polar dinosaurs. South African Journal of Science 94, 137-141.

Dickson, J.A.D., 1966. Carbonate identification and genesis as revealed by staining. Journal of Sedimentary Petrology 36, 491-505.

Ditchfield, P.W., Marshall, J.D., Pirrie, D., 1994. High latitude paleotemperature variation: new data from the Tithonian to Eocene of James Ross Island, Antarctica. Palaeogeography, Palaeoclimatology, Palaeoecology 107, 79-101.
Doyle, P., 1987. The Cretaceous Dimitobelidae (Belemnitida) of the Antarctic Peninsula region. Palaeontology 30, 147-177.

Doyle, P., 1988. The belemnite family Dimitobelidae in the Cretaceous of Gondwana. In: Wiedmann, I., Kullman, J. (Eds.), Cephalopods Past and Present. Schweizerbart'sche Verlagsbuchandlung, Stuttgart, pp. 539-552.

Doyle, P., 1990. New records of dimitobelid belemnites from the Cretaceous of James Ross Island, Antarctica. Alcheringa 14, 159-175.

Doyle, P., 1992. A review of the biogeography of Cretaceous belemnites. Palaeogeography, Palaeoclimatology, Palaeoecology 92, 207-221.

Doyle, P., Pirrie, D., 1999. Belemnite distribution patterns: implications of new data from Argentina. In: Oloriz, F., Rodriguez-Tovar, F.J. (Eds.), Advancing Research on Living and Fossil Cephalopods. Kluwer Academic, New York, pp. 419-436.

Erbacher, J., Huber, B.T., Norris, R.D., Markey, M., 2001. Increased thermohaline stratification as a possible cause for an ocean anoxic event in the Cretaceous period. Nature 409, 325-327.

Frakes, L.A., Francis, J.E., 1988. A guide to Phanerozoic cold polar climates from high-latitude ice-rafting in the Cretaceous. Nature 333, 547-549.

Frakes, L.A., Francis, J.E., Syktus, J.I., 1992. Climate Modes of the Phanerozoic. Cambridge University Press, Cambridge, 274 pp.

Francis, J.E., Poole, I., 2002. Cretaceous and early Tertiary climates of Antarctica: evidence from fossil wood. Palaeogeography, Palaeoclimatology, Palaeoecology 182, 47-64.

Gregory, R.T., Douthitt, C.B., Duddy, I.R., Rich, P.V., Rich, T.H., 1989. Oxygen isotope composition of carbonate concretions from the lower Cretaceous of Victoria, Australia: implications for the evolution of meteoric waters on the Australian continent in a paleopolar environment. Earth and Planetary Science Letters 92, 27-42.

Huber, B.T., Hodell, D.A., Hamilton, C.P., 1995. Middle-Late Cretaceous climate of the southern high latitudes: stable isotopic evidence for minimal equator-to-pole thermal gradients. Geological Society of America, Bulletin 107, 1164-1191.

Huber, B.T., Norris, R.D., MacLeod, K.G., 2002. Deep-sea paleotemperature record of extreme warmth during the Cretaceous. Geology 30, 123-126.

Hudson, J.D., Anderson, T.F., 1989. Ocean temperatures and isotopic compositions through time. Transactions of the Royal Society of Edinburgh, Earth Sciences 80, 183-192.

Ineson, J.R., 1989. Coarse-grained submarine fan and slope apron deposits in a Cretaceous back-arc basin, Antarctica. Sedimentology 36, 793-819.

Ludbrook, N.H., 1966. Cretaceous biostratigraphy of the Great Artesian Basin in South Australia. Bulletin of the Geological Survey of South Australia 40, 1-223.

Marshall, J.D., 1992. Climatic and oceanographic isotopic signals from the carbonate rock record and their preservation. Geological Magazine 129, 143-160.

Miller, K.G., Barrera, E., Olsson, R.K., Sugarman, P.J., Savin, S.M., 1999. Does ice drive early Maastrichtian eustasy? Geology 27, 783-786.

Miller, K.G., Sugarman, P.J., Browning, J.V., Kominz, M.A., Hernández, J.C., Olsson, R.K., Wright, J.D., Feigenson, M.D., Sickel, W.V., 2003. Late Cretaceous chronology of large, rapid sealevel changes: glacioeustasy during the greenhouse world. Geology 31, 585-588.

Pirrie, D., Marshall, J.D., 1990. High paleolatitude Late Cretaceous paleotemperatures; new data from James Ross Island, Antarctica. Geology 18, 31-34.

Pirrie, D., Doyle, P., Marshall, J.D., Ellis, G., 1995. Cool Cretaceous climates-new data from the Albian of Western Australia. Journal of the Geological Society, London 152, 739-742.

Price, G.D., Valdes, P.J., Sellwood, B.W., 1998. A comparison of GCM simulated Cretaceous 'greenhouse' and 'icehouse' climates: 
implications for the sedimentary record. Palaeogeography, Palaeoclimatology, Palaeoecology 142, 123-138.

Riccardi, A.C., 1971. Estratigrafia en el oriente de la Bahia de la Lancha, Lago San Martin, Santa Cruz, Argentina. Museo de la Plata, Geologia 7, 61, 245-318.

Riccardi, A.C., 1988. The Cretaceous System of southern South America. Geological Society of America, Memoir 168, $161 \mathrm{pp}$.

Riccardi, A.C., Medina, F.A., 2002. The Beudanticeratinae and Cleoniceratinae (Ammonitida) from the Lower Albian of Patagonia. Revue de Paléobiologie 21, 1-61.

Riccardi, A.C., Aguirre Urreta, M.B., Medina, F.A., 1987. Aconeceratidae (Ammonitina) from the Hauterivian-Albian of southern Patagonia. Palaeontographica A 196, 105-185.

Rich, P.V., Rich, T.H., Wagstaff, B.E., McEwen Mason, J., Douthitt, C.B., Gregory, R.T., Felton, E.A., 1988. Evidence for low temperatures and biologic diversity in Cretaceous high latitudes of Australia. Science 242, 1403-1406.

Riding, J.B., Crame, J.A., 2002. Aptian to Coniacian (Early-Late Cretaceous) palynostratigraphy of the Gustav Group, James Ross Basin, Antarctica. Cretaceous Research 23, 739-760.
Sellwood, B.W., Price, G.D., Valdes, P.J., 1994. Cooler estimates of Cretaceous climate. Nature 370, 453-455.

Shackleton, N.J., Kennett, J.P., 1975. Paleotemperature history of the Cenozoic and initiation of Antarctic glaciation: oxygen and carbon isotope analysis in DSDP sites 277, 279, and 281. Initial Reports of the Deep Sea Drilling Project 29, 743-755.

Stevens, G.R., 1965. The Jurassic and Cretaceous belemnites of the Indo-Pacific region. Palaeontological Bulletin of the Geological Survey of New Zealand 36, 283 pp

Stoll, H.M., Schrag, D.P., 2000. High-resolution stable isotope records from the Upper Cretaceous rocks of Italy and Spain: glacial episodes in a greenhouse planet. Geological Society of America, Bulletin 112, 308-319.

Voigt, S., Wilmsen, M., Mortimore, R.N., Voigt, T., 2003. Cenomanian palaeotemperatures derived from the oxygen isotopic composition of brachiopods and belemnites: evaluation of Cretaceous palaeotemperature proxies. International Journal of Earth Sciences 92, 285-299.

Whitehouse, F.W., 1924. Dimitobelidae-a new family of Cretaceous belemnites. Geological Magazine 61, 410-416. 